\title{
Persistent rubella-specific IgM-antibody in the cerebrospinal fluid of a child with congenital rubella
}

\author{
TIMO VESIKARI, OLLI H MEURMAN, AND RITVA MÄKI \\ Department of Paediatrics, Tampere Central Hospital, and Department of Virology, University of Turku, \\ Finland
}

SUMMARY Rubella-specific IgM-antibody was detected, using a solid-phase radioimmunoassay (RIA) method, in the CSF of a child with congenital rubella at ages 3 and 4 years. No rubellaspecific IgM was found in the CSF of 20 other children with congenital rubella, and the ratios of rubella-specific IgG RIA antibody titres in serum and CSF were normal.

In infants with congenital rubella infection the virus excretion gradually ceases during the first year of life. ${ }^{1}$ Persistence of the virus in the lens up to 3 years has been described. ${ }^{2}$ Furthermore, rubella virus antigen has been demonstrated in the thyroid at age $5 \frac{3}{4}$ years in a child with congenital rubella. ${ }^{3}$ Clinically, there are various late onset manifestations in congenital rubella - such as, diabetes, hypothyroidism, and growth hormone deficiency. Viral persistence and reactivation may have a role in these and also in the progressive hearing loss in children with congenital rubella. ${ }^{4}$

The most remarkable late onset manifestation of congenital rubella however, is a slow central nervous system infection resembling SSPE. ${ }^{5-6}$ These patients had high titres of rubella antibody both in serum and CSF. Therefore the presence of rubella antibody in the CSF may be an indicator of viral persistence or reactivation in the CNS. We looked for rubella antibody in the CSF of 21 children with congenital rubella, and found evidence suggesting prolonged infection in one.

\section{Patients and methods}

21 children aged 3 to 12 years with confirmed or suspected congenital rubella were studied. In 5 cases the diagnosis was made during the first year of life by the demonstration of either rubella-specific IgM antibodies or persistent total rubella haemagglutination-inhibiting (HI) antibodies. In the remaining 16 children the diagnosis was first made sero-

Department of Paediatrics, Tampere Central Hospital TIMO VESIKARI, paediatrician

Department of Virology, University of Turku

OLLI H MEURMAN, virologist

Department of Microbiology, Tampere Central Hospital RITVA MÄKI, microbiologist logically between 1 and 4 years of age. In addition to demonstrable rubella $\mathrm{HI}$ antibodies the children had clinical findings consistent with congenital rubella, and there was a history of suspected or confirmed maternal rubella in pregnancy in 17 cases. Each child had a hearing defect, ranging from slight unilateral to severe bilateral. In fact, many of the older children were detected during a survey for rubella antibody in congenital hearing loss. ${ }^{7}$ Other principal symptoms and signs related to congenital rubella are listed in the Table.

Solid-phase radioimmunoassay (RIA) for rubella antibody. The procedure has been described in detail. ${ }^{14}$ Briefly, partially purified rubella virus antigen was absorbed on to polystyrene balls. After incubation with sera or CSF specimens, the attached rubella-specific IgG and IgM antibodies were demonstrated using antihuman $\gamma$-chain or antihuman $\mu$-chain antibody labelled with ${ }^{125}$ I. For the demonstration of rubella IgM antibody the specificity of the reaction was checked using a control antigen preparation made from uninfected Vero cells. Furthermore, the IgM-positive specimens were studied for the presence of rheumatoid factor using a RIA method. ${ }^{8}$

Rubella HI titration was done as described previously. ${ }^{9}$ The sera were pretreated with kaolin and absorbed with chicken red blood cells.

The total immunoglobulin (IgG and IgM) concentrations of CSF were determined nephelometrically using commercial antisera (Behringwerke).

\section{Results}

19 of the 21 children had demonstrable rubella HI antibody in the serum at the time of study (Table); one of the 2 seronegative children also lacked rubella 
Table Rubella antibodies in serum and cerebrospinal fluid in 21 children with congenital rubella syndrome

\begin{tabular}{|c|c|c|c|c|c|c|}
\hline \multirow[t]{3}{*}{ Case } & \multirow{3}{*}{$\begin{array}{l}\text { Main } \\
\text { symptoms* }\end{array}$} & \multirow{3}{*}{$\begin{array}{l}\text { Age at } \\
\text { study } \\
\text { (years) }\end{array}$} & \multicolumn{4}{|c|}{ Rubella antibodies } \\
\hline & & & \multicolumn{2}{|l|}{ Serum } & \multicolumn{2}{|c|}{$C S F-R I A$} \\
\hline & & & $H I$ & $R I A$ & $I g G$ & $I g M$ \\
\hline 1 & $\begin{array}{l}\text { Retinopathy. } \\
\text { Convulsions }\end{array}$ & $\begin{array}{l}3 \\
4\end{array}$ & $\begin{array}{l}20 \\
20\end{array}$ & $\begin{array}{l}2048 \\
4096\end{array}$ & $\begin{array}{l}32 \\
16\end{array}$ & $\begin{array}{r}32 \\
8\end{array}$ \\
\hline 2 & None & 3 & 20 & 1024 & $<4$ & $<4$ \\
\hline 3 & Retinopathy & 3 & 80 & 64000 & 128 & $<4$ \\
\hline 4 & Hyperkinetic & 4 & 80 & 8000 & 8 & $<4$ \\
\hline 5 & Retinopathy & 5 & 10 & 8000 & 8 & $<4$ \\
\hline 6 & Hyperkinetic & 5 & 20 & 8000 & 16 & $<4$ \\
\hline 7 & Retinopathy & 5 & 20 & 2048 & 32 & $<4$ \\
\hline 8 & Retinopathy & 8 & 40 & 16000 & 8 & $<4$ \\
\hline 9 & None & 8 & $<10$ & 16 & $<4$ & $<4$ \\
\hline 10 & $\begin{array}{r}\text { Psychomotor } \\
\text { retardation }\end{array}$ & 8 & 10 & 64 & $<4$ & $<4$ \\
\hline 11 & Slight paresis & 8 & 80 & 8000 & 8 & $<4$ \\
\hline 12 & Retinopathy & 8 & 40 & 8000 & 4 & $<4$ \\
\hline 13 & $\begin{array}{l}\text { Retinopathy. } \\
\text { Skeletal } \\
\text { anomalies }\end{array}$ & 9 & 40 & 32000 & 32 & $<4$ \\
\hline 14 & $\begin{array}{l}\text { Retinopathy. } \\
\text { Slight paresis }\end{array}$ & 9 & 20 & 4096 & 16 & $<4$ \\
\hline 15 & $\begin{array}{l}\text { Retinopathy. } \\
\text { MBD }\end{array}$ & 9 & 20 & 4096 & 16 & $<4$ \\
\hline 16 & None & 9 & $<10$ & $<16$ & $<4$ & $<4$ \\
\hline 17 & $\begin{array}{l}\text { Psychomotor } \\
\text { retardation }\end{array}$ & 10 & 320 & 8000 & 16 & $<4$ \\
\hline 18 & None & 10 & 10 & 512 & $<4$ & $<4$ \\
\hline 19 & $\begin{array}{l}\text { Retinopathy. } \\
\text { Skeletal } \\
\text { anomalies }\end{array}$ & 10 & 80 & 32000 & 32 & $<4$ \\
\hline 20 & $\begin{array}{l}\text { Retinopathy. } \\
\text { Microcephaly }\end{array}$ & 11 & 10 & 4096 & $<4$ & $<4$ \\
\hline 21 & $\begin{array}{l}\text { Psychomotor } \\
\text { retardation }\end{array}$ & 12 & 20 & 8000 & $<4$ & $<4$ \\
\hline
\end{tabular}

* All children had hearing defects.

$\mathrm{MBD}=$ Minimal brain damage.

RIA antibody. Both children had had rubella HI antibody several years earlier, at ages 2 years 8 months and 3 years 10 months respectively, and therefore had apparently lost rubella antibody. In the remaining 19 children, the rubella $\mathrm{HI}$ antibody titres ranged from $1: 10$ to $1: 320$ and the RIA titres from $1: 64$ to $1: 64000$. Rubella-specific IgM was not demonstrable by RIA in any of the sera.

Rubella-specific IgG antibody was detected in the CSF of 14 children (Table). There was usually a good correlation between the serum and CSF rubella RIA antibody titres, and the CSF/serum ratio ranged from 1:500 to 1:2000. The total protein of CSF was well within normal limits in each case (range 0.05 to $0.68 \mathrm{~g} / \mathrm{l}$ ). There was no nephelometrically detectable IgM in any of the CSF specimens.

Rubella-specific IgM antibody was found in the CSF in one patient (Case 1, Table). This child had hepatosplenomegaly at birth, but was otherwise without symptoms. At 6 months he had short episodes of convulsions. The ophthalmological examination at this age was described as normal, but at age $1 \frac{3}{4}$ years and later, retinal pigmentation was detected. The hearing defect was also detected when he was 13 years. There has apparently been no progression of the hearing loss which is moderate and bilateral. The EEG was slightly abnormal at age 3 years, but there were no further neurological symptoms after age 6 months, and the child remains well and appears of normal intelligence.

Attempts at rubella virus isolation at 3 years were made from CSF, from a lymph node biopsy, and from peripheral blood lymphocytes using RK 13 cells. All tests were negative.

The test for rubella IgM antibody in the CSF, first found positive at 3 years, was repeated again 3 months later and again at 4 years. In the first repeat the same titres of rubella-specific IgM and IgG antibody (each 1:32) were found as in the first CSF specimen. By age 4 years the CSF rubella antibody titres had decreased, but there was still some rubellaspecific IgM antibody detectable by RIA (Table). There was no reaction with control antigen preparation, and no rheumatoid factor could be detected in the CSF by RIA.

\section{Discussion}

This study showed no indication of chronic infection in most children with congenital rubella. However, the finding of rubella-specific IgM antibody in one patient at ages 3 and 4 years suggests that in some patients with congenital rubella the virus may persist in the CNS for years and thus cause continuous antigenic stimulation. Nevertheless, there have been no signs of progressive neurological disease in the patient, and we were unable to isolate the virus from him.

Conceivably, however, a patient with virusspecific IgM antibody in CSF might be a candidate for later reactivation of the virus and possible development of a late onset rubella encephalitis. However, our finding of rubella-specific IgM in the CSF is different from the patients with progressive rubella panencephalitis after congenital rubella at a later age. In the latter cases only IgG class rubella antibody was found in the CSF. ${ }^{10-11}$ Therefore we think that our case represents the continuous presence of rubella antigen in the CNS rather than reactivation of the virus. A high titre of rubella antibody and a raised concentration of IgM in the CSF was described by Lebon and Lyon in a patient with noncongenital progressive rubella encephalitis. ${ }^{12-13}$

If the above speculation is right a sensitive and specific method, such as RIA, for the demonstration of rubella-specific antibody in CSF might be useful for two reasons: follow-up of persistence of infectious process in the CNS in cases with congenital 
rubella, and detection of possible cases of reactivation at a later age. It is not yet certain whether systematic screening for CSF rubella antibody in children with congenital rubella is recommended.

\section{References}

1 Cooper L Z, Krugman S. Clinical manifestations of postnatal and congenital rubella. Arch Ophthalmol 1967; 77: 434-9.

2 Menser M A, Harley J D, Hertzberg R, Dorman D C, Murphy A M. Persistence of virus in lens for three years after prenatal rubella. Lancet 1967; 2: 387-8.

3 Ziring P R, Gallo G, Finegold M, Buimovici-Klein E, Ogra P. Chronic lymphocytic thyroiditis: identification of rubella virus antigen in the thyroid of a child with congenital rubella. $J$ Pediatr 1977; 90: 419-20.

4 Hanshaw J B, Dudgeon J A. Viral diseases of the fetus and newborn. Major problems in clinical pediatrics, vol. 17. Philadelphia: W B Saunders, 1978: 17-96.

5 Townsend J J, Baringer J R, Wolinsky J S, et al. Progressive rubella panencephalitis. Late onset after congenital rubella. $N$ Engl J Med 1975; 292 : 990-3.

- Weil M L, Itabashi H H, Cremer N E, Oshiro L S, Lennette E H, Carnay L. Chronic progressive panencephalitis due to rubella virus simulating subacute sclerosing panencephalitis. N Engl J Med 1975; 292 : 994 8.

7 Ojala P, Vesikari T, Elo O. Rubella during pregnancy as a cause of congenital hearing loss. Am J Epidemiol $1973 ; 98$ : 395-401.
8 Meurman O H, Ziola B R. IgM class rheumatoid factor interference in the solid-phase radioimmunoassay of rubella-specific IgM antibodies. J Clin Pathol 1978; 31 : 483-7.

- Halonen P E, Stewart J A, Hall A D. Rubella hemagglutinin prepared in serum free suspension culture of BHK 21 cells. Ann Med Exp Biol Fenniae 1967; 45: 182-5.

10 Cremer N E, Oshiro L S, Weil M L, Lennette E H, Itabashi $\mathbf{H ~ H}$, Carnay $\mathbf{L}$. Isolation of rubella virus from brain in chronic progressive panencephalitis. J Gen Virol 1975; 29 : 143-53.

11 Vandvik B, Weil M L, Grandien M, Norrby E. Progressive rubella virus panencephalitis: synthesis of oligoclonal virus-specific IgG antibodies and homogenous free light chains in the central nervous system. Acta Neurol Scand 1978; 57: 53-64.

12 Lebon P, Lyon G. Letter: Non-congenital rubella encephalitis. Lancet 1974; $2: 468$.

13 Schuller E, Delasnerie N, Allinquant B, Lebon P. Intrathecal rubella and RNA antibody synthesis in multiple sclerosis and progressive rubella panencephalitis. Biomedicine 1977; 27 : 139-41.

14 Meurman O H, Viljanen M K, Granfors K. Solid phase radioimmunoassay of rubella virus immunoglobulin $\mathbf{M}$ antibodies. Comparison with sucrose density gradient centrifugation test. J Clin Microbiol 1977; 5: 257-62.

Correspondence to Dr T Vesikari, Tampere Central Hospital, Department of Paediatrics, 33520 Tampere 52, Finland.

Received 20 February 1979 